\title{
Impact of Secondary Flow on Bed Form and Sediment Transport in a Meandering Channel for Overbank Flow
}

\author{
Taisuke ISHIGAKI ${ }^{1}$, Koji SHIONO ${ }^{2}$, Ponnambalam RAMESHWARAN ${ }^{2}$, \\ Cecil F. SCOTT ${ }^{2}$ and Yasunori MUTO ${ }^{3}$ \\ 1. Member of JSCE, Dr. of Eng., Ujigawa Hydraulics Laboratory, DPRI, Kyoto University \\ (Fushimi, Kyoto 612-8235, Japan) \\ 2. $\mathrm{PhD}$, Civil and Building Engineering, Loughborough University \\ (Loughborough, Leics, LE11 3TU, UK) \\ 3. Member of JSCE, PhD, Ujigawa Hydraulics Laboratory, DPRI, Kyoto University
}

\begin{abstract}
An investigation of interaction between bed form and secondary flow in a compound meandering channel with straight floodplain banks for overbank was carried out. The mobile bed form in the main channel was measured by photogrammetry and the secondary flow was first visualized with a submergible video camera and then measured using three component laser Doppler anemometer. The results of the bed form and secondary flow during flood indicate that there exists a certain relationship between the bed form and secondary flow. The secondary flow induced by the floodplain flow in the main channel generates another secondary flow cell owing to the bed form change. Those secondary flow cells make sand bars crossing the main channel, particularly, in the cross-over region. Sediment transport rate reduces at an early stage of flooding owing to strong interaction between the floodplain flow and the main channel flow.
\end{abstract}

Key words: Flood hydraulics, Bed form, Secondary flow, Sediment transport rate

\section{Introduction}

Severe flooding occurs worldwide every year as urban areas and agricultural lands are inundated. This threatens all kinds of natural life as well as damaging national economies due to lost production and the cost of repairs. This kind of flooding is particularly severe on continental land masses but is also a frequent occurrence even for islands such as the UK or Japan. In high river flow conditions, rivers often flow in an overbank condition, flooding adjacent plains and a large exchange of momentum takes place between a faster flow in a main channel and a slower flow in a flood plain. There are also secondary flows generated by anisotropic turbulence arising from the irregularity of the boundary in a straight compound channel ${ }^{7)}$, and the flood plain flow rolling over the main channel flow in a meandering compound channel ${ }^{1), 2), 3), 8)}$. Such hydraulic conditions increase the flow resistance and the resulting turbulence and secondary flows will lead to a rapid change of bed form for a mobile bed channel. These flow characteristics are known to be strongly affected by many geometric parameters like channel sinuosity, aspect ratio, surface roughness, and so on.
Recent work on the UK Flood Channel Facility (FCF) at HR Wallingford has made a significant impact on our understanding of various hydraulic aspects of river flow for overbank. The work on the FCF included fundamental research problems in sediment mechanics. The mean velocity in the meandering channel with flat beds for overbank conditions is significantly reduced by secondary flow and turbulence generated by interaction between the flood plain flow and the main channel flow ${ }^{8), 9)}$. The result on mobile beds with graded sediment shows a decrease in sediment transport rates in the early stages of flooding compared with that at the bankfull stage ${ }^{6)}$. Further investigation on the interaction of the floodplain flows on sediment bed forms, transport rates and channel geometry, arising from secondary flow and turbulence in the main channel is necessary in order to get better understanding on channel behaviour under flooding conditions. This paper presents further work on sediment transport in meandering channels for overbank flow including bed forms during flooding, visualization of secondary flow with measured secondary flow using LDA and sediment transport rates. 


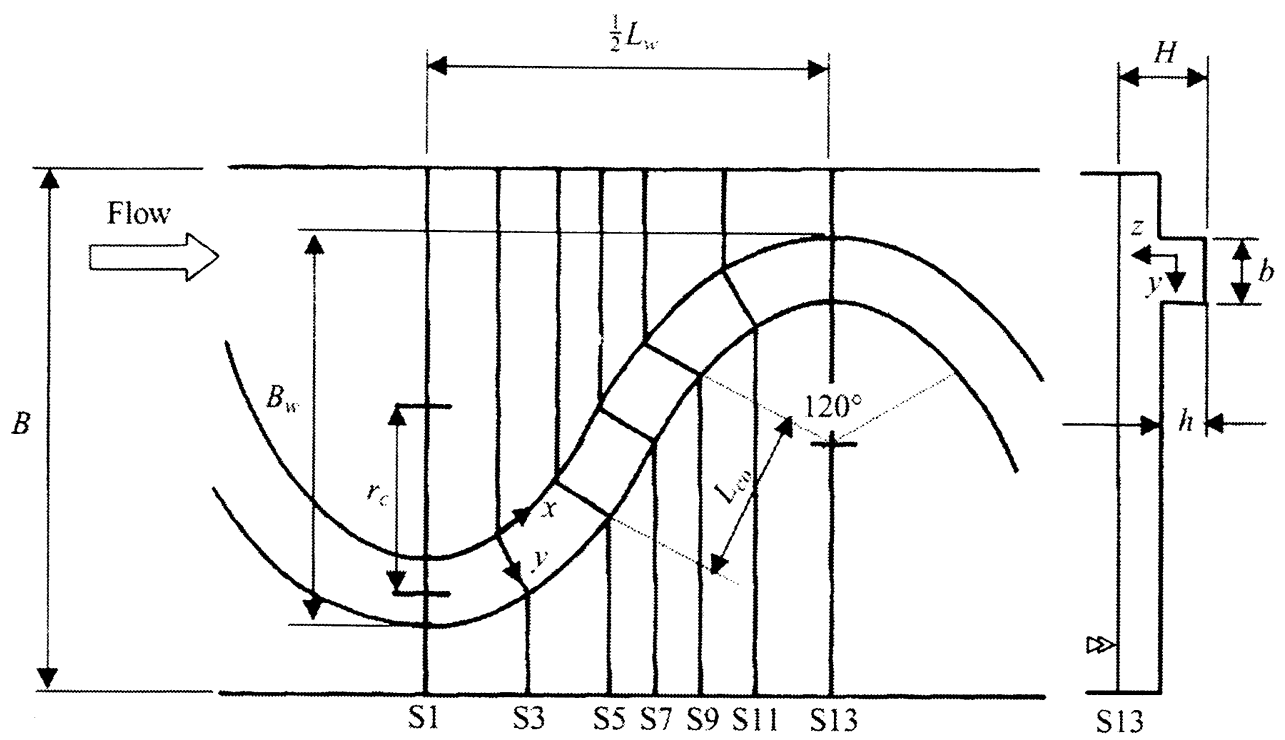

Fig. 1 Meander channel configuration for test section.

Table 1 Geometric parameters of two-stage channel.

\begin{tabular}{l|c} 
Sinuosity & 1.384 \\
Floodplain width $(\mathrm{m})$ & 2.4 \\
Meander length (m) & 3.4 \\
Meander belt width (m) & 1.815 \\
Main channel width (m) & 0.4 \\
Main channel depth (mm) & $40 \& 75$ \\
Valley slope & 0.002 \\
\hline
\end{tabular}

\section{Experimental work}

The test flume is $2.4 \mathrm{~m}$ wide $13 \mathrm{~m}$ long and $0.5 \mathrm{~m}$ deep with having a sand re-circulation facility. A meandering channel was set in the form of a 120 degree meandering channel with a cross-over length of $750 \mathrm{~mm}$ and a flat bed by placing polystyrene boards as flood plains whose surface is hydraulically smooth. Three meanders were built in the flume. The details of channel configuration and dimensions are in Fig. 1 and Tablc 1 rcspectively. Meandering rivers usually have a ratio of meander length to the main channel width of about 10 according to Peterson ${ }^{5)}$, this experimental channel is very similar. Uniform sand with a mean diameter of $0.85 \mathrm{~mm}$ was used in the main channel. The main channel flow depth was controlled by placing the sand and in the present study it was initially set to $40 \mathrm{~mm}$ or $75 \mathrm{~mm}$ with the same slope as the valley slope which gives an aspect ratio $\mathrm{b} / \mathrm{h}$ of 10 and 5.33 respectively. A flow rate was measured by calibrated orifice plate in a delivery pipe and a water surface slope was measured by means of a point gauge. Velocity measurements were carried out using a TSI 3-component laser Doppler anemometer (LDA). A 3-D morphological bed form was measured using automated digital photogrammetry. The sediment transport rate was manually determined by collecting sediment from the sand re-circulation pipe.

\section{Bed form}

Change of bed form for $\mathrm{b} / \mathrm{h}=10$ was first observed with various flood depths and is shown in Fig. 2. It should be noted that the figure was plotted in gray scale. Deeper depth is darker colour and shallower depth is light colour. The bed form at the bankfull, $\mathrm{Dr}=0$, shows a typical bed form for an inbank meandering channel flow, that is the thalweg (line of maximum depth) deviating from the channel centreline to the outer bend. A sand bar also appears in the centre of the channel in the latter section of the meander even the ratio of the meander length to the meander belt width is smaller than the natural meandering channel range between 2 and $4^{4)}$. When the flow becomes overbank at the water depth, $\mathrm{Dr}=0.15$, the sand bar starts hreaking away. As the water depth increases further more to $\mathrm{Dr}=0.30$, the bed form becomes many ripples. When the water depth is at $\mathrm{Dr}=0.35$, a number of sand bars (ridges) with an angle start appearing near the upstream main channel bank (left hand side in Fig. 2), and the water depth increases further more to $\mathrm{Dr}=0.45$, distinct sand bars crossing the main channel distinctly appear. However the water depth increases more to $\mathrm{Dr}=0.50$, they start breaking away as if the bed form is getting flat. From the experimental results for the secondary flow structures obtained from large and small scales of the meandering channels with a flat bed for overbank flows ${ }^{8)}$, an existence of a number of secondary flow cells in the cross-over section was illustrated. For a mobile bed in the main channel, this experiment confirmed that these cell make sand bars. 


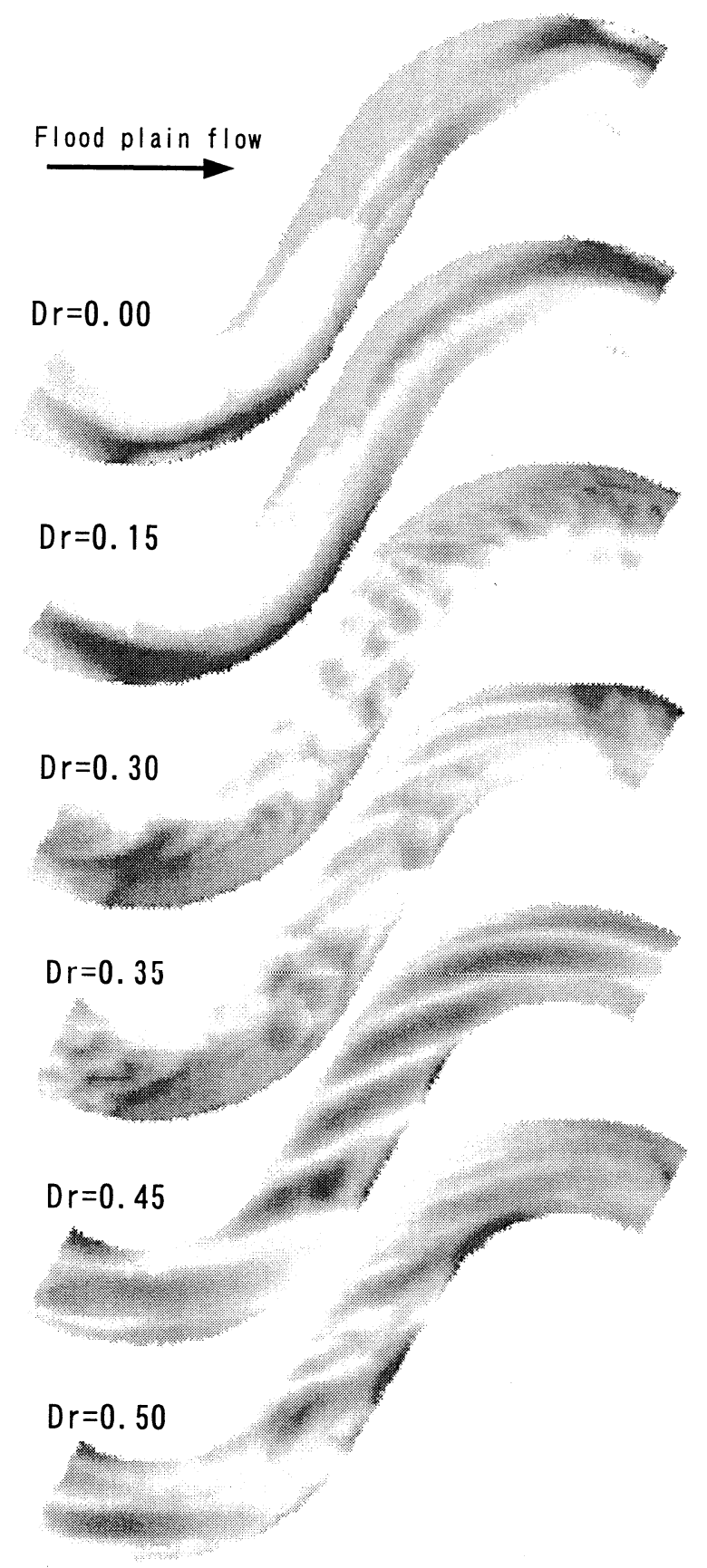

Fig. 2 Bed forms with various depths. $(\mathrm{b} / \mathrm{h}=10)$

\section{Secondary flow}

In order to understand how the sand bars are generated by secondary flow, an investigation of the secondary flow structure in the main channel was carried out using first a submergible lens with a remote controlled video camera to visualize the secondary flow. Neutral-buoyancy plastic beads (a diameter of $0.45 \mathrm{~mm}$ with a specific gravity of 1.05 ) as tracers were leased at about 1 meter upstream of the test section with a minimum disturbance. The lens was set at about $300 \mathrm{~mm}$ downstream from the test section. The test section was illuminated with an ordinary slide projector with a power of $150 \mathrm{~W}$.
A captured video source was processed by commercially available software (PhotoShop). More details for the visualization method can be seen in literature ${ }^{3)}$. It is valuable in seeing movement of particles captured by the video camera, however it does not give the magnitudes of three components of velocity. In order to obtain the magnitudes, a 3-component laser Doppler anemometer system was used. The system consists of two $10 \mathrm{~m}$ long fibre optic cables connection the laser and signal processing system to two $15 \mathrm{~mm}$ diameter submergible probe heads. The probe heads were mounted on a TSI two-axis traverser system covered $0.6 \mathrm{~m}$ in both vertical and transverse directions with a resolution of $0.1 \mathrm{~mm}$. The LDA system was operated in random mode for only measuring the mean flow. The data rate was about $1 \mathrm{KHz}$ and the duration of data recording was set to 1 minute. It is easier to understand the secondary flow structure with combining visualization and LDA results. Both results at the bend apex for $\mathrm{Dr}=0.45$ with the initial $\mathrm{b} / \mathrm{h}=10$ are shown in Fig. 3 . It can be seen from the figure that both visualization and LDA results match very well and there are a number of secondary flow cells observed in this section. However it is very difficult to understand where these cells come from. We undertook several measurements along the sand bar passing the bend apex and their results of secondary flow vectors for $\mathrm{Dr}=0.45$, watching from the downstream for each measurement section, are shown in Fig. 4 together with the location of the measurement sections. As shown in the figure the measurement sections were set perpendicular to the flood plain bank, however, in order to see the secondary flow structure within the reach along a trough, A-F, the secondary flow vectors were rotated with an angle of the trough with reference to the floodplain bank. It is clearly seen from Fig. 4 that the anti-clockwise secondary flow cell is generated at the edge of the floodplain, section A. This cell increases in size while the bed level gets deeper between sections $\mathrm{A}$ and $\mathrm{D}$, meaning that the bed erosion occurs, then decreases in size as the bed level gets shallower after section $\mathrm{C}$ and finally disappears. It is noticed that there is the clockwise secondary flow cell on the right side of the ridge generated by the cross-flow over the ridge (see sections B-D). This cross-flow is actually the anticlockwise secondary flow generated by the flood plain flow between next upstream ridge. This cell increases in size after there is no the cross-flow over the ridge at section $\mathrm{E}$, however the strength of the cell is weaken as if it is a residual flow. The evidence of weakening the cell can be seen from reducing the bed level after section $\mathrm{D}$ in the latter 


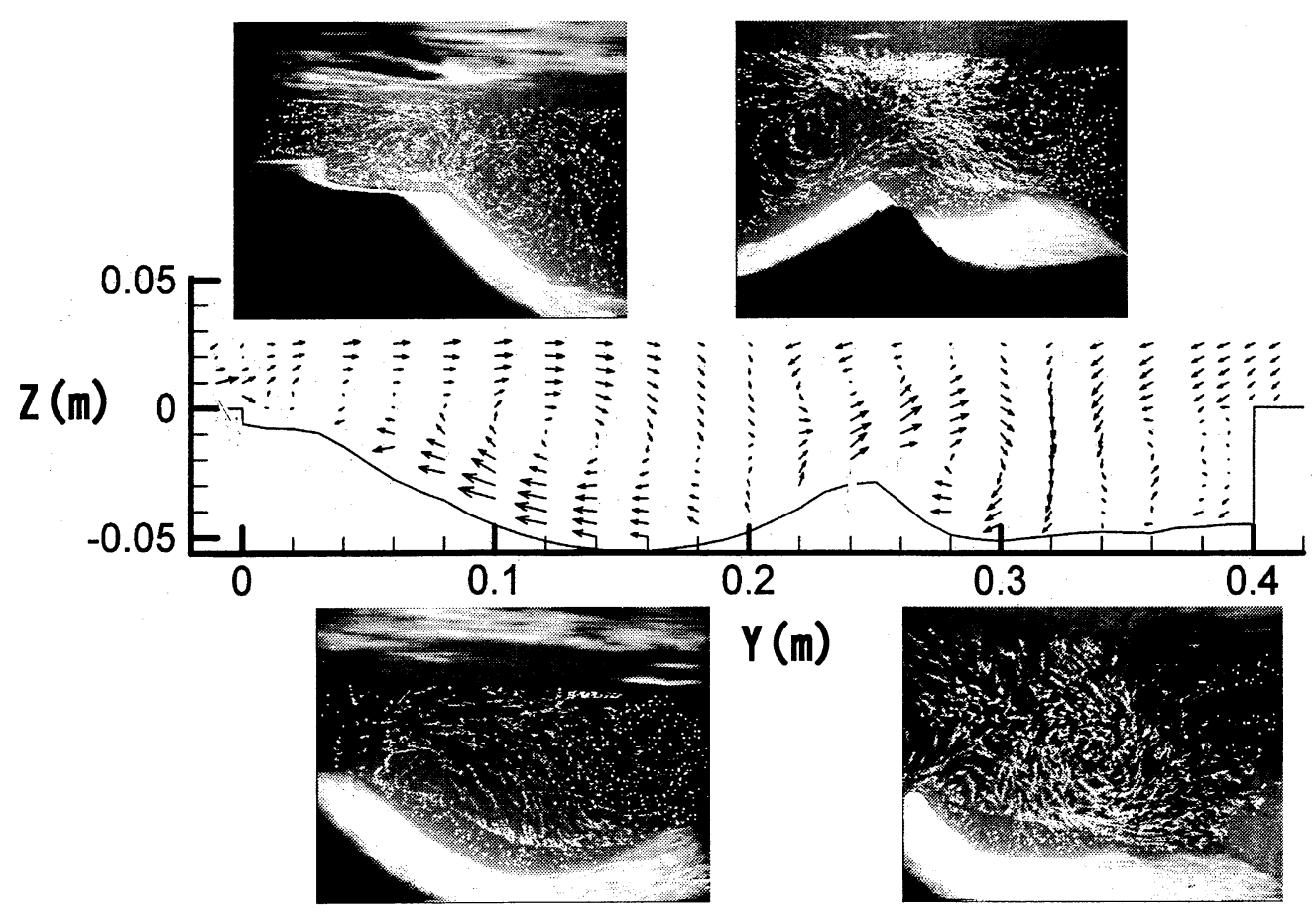

Fig. 3 Visualization and LDA measurement for secondary flow at a downstream bend apex in the test section. (Dr=0.45)
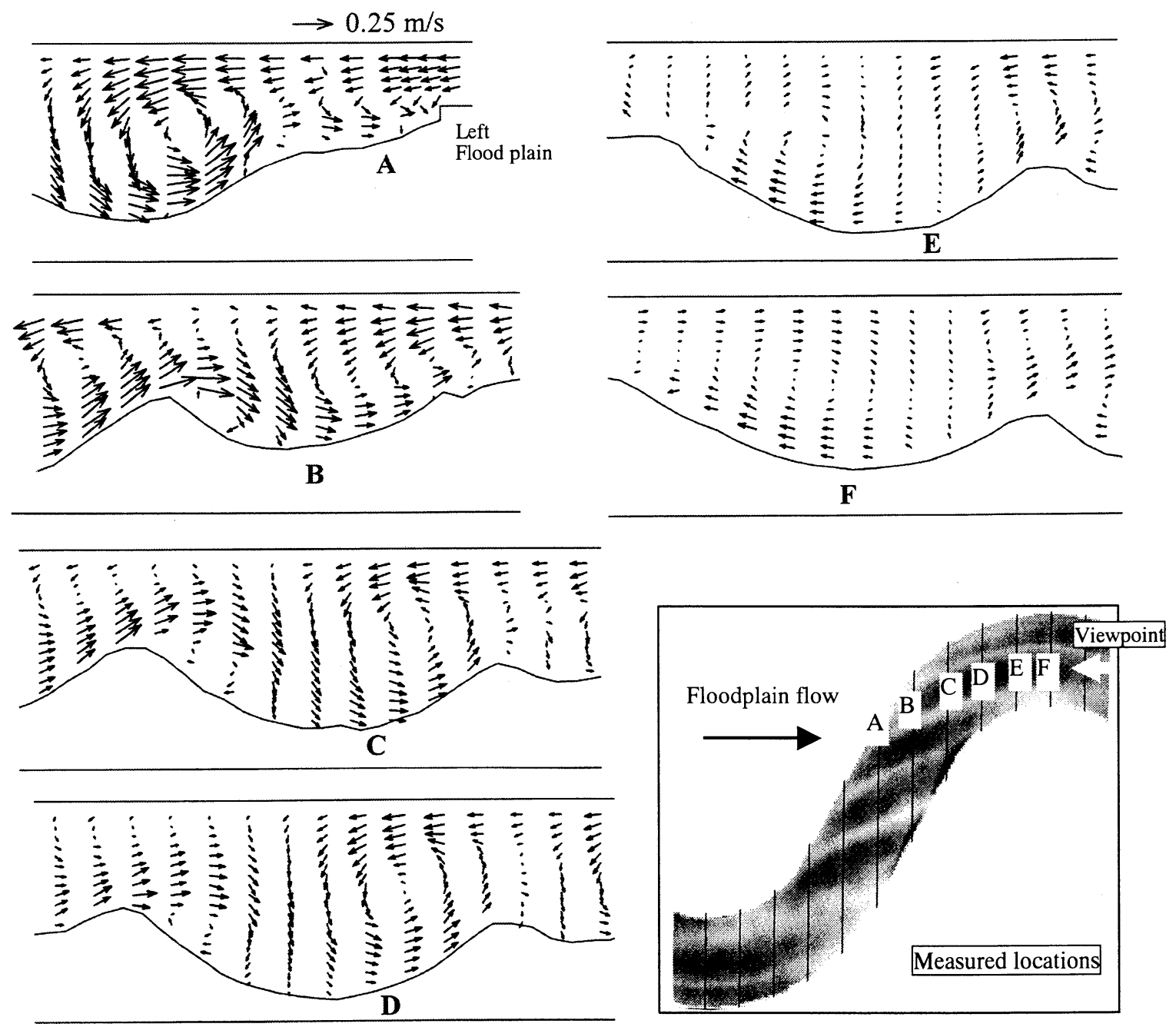

Fig. 4 Secondary flow vectors along a trough, together with locations of LDA measurements ( $\mathrm{Dr}=0.45)$. 


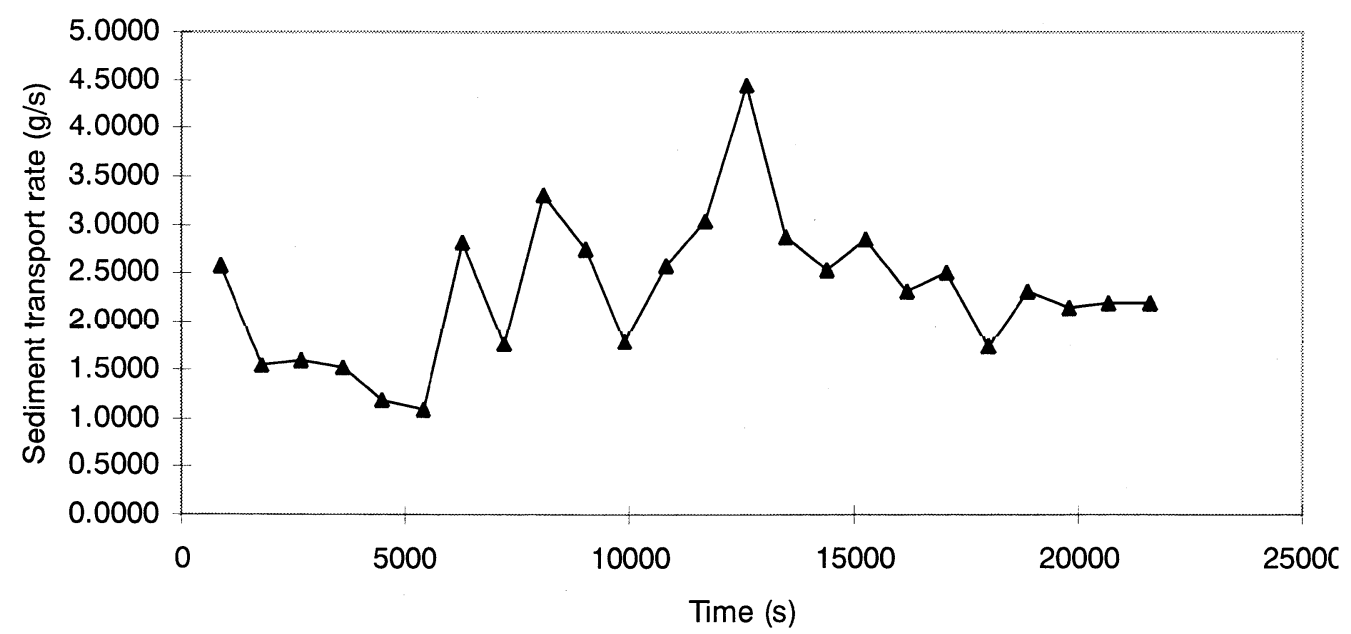

Fig. 5 Sediment transport rate with time. $(\mathrm{Dr}=0.50, \mathrm{~b} / \mathrm{h}=10)$
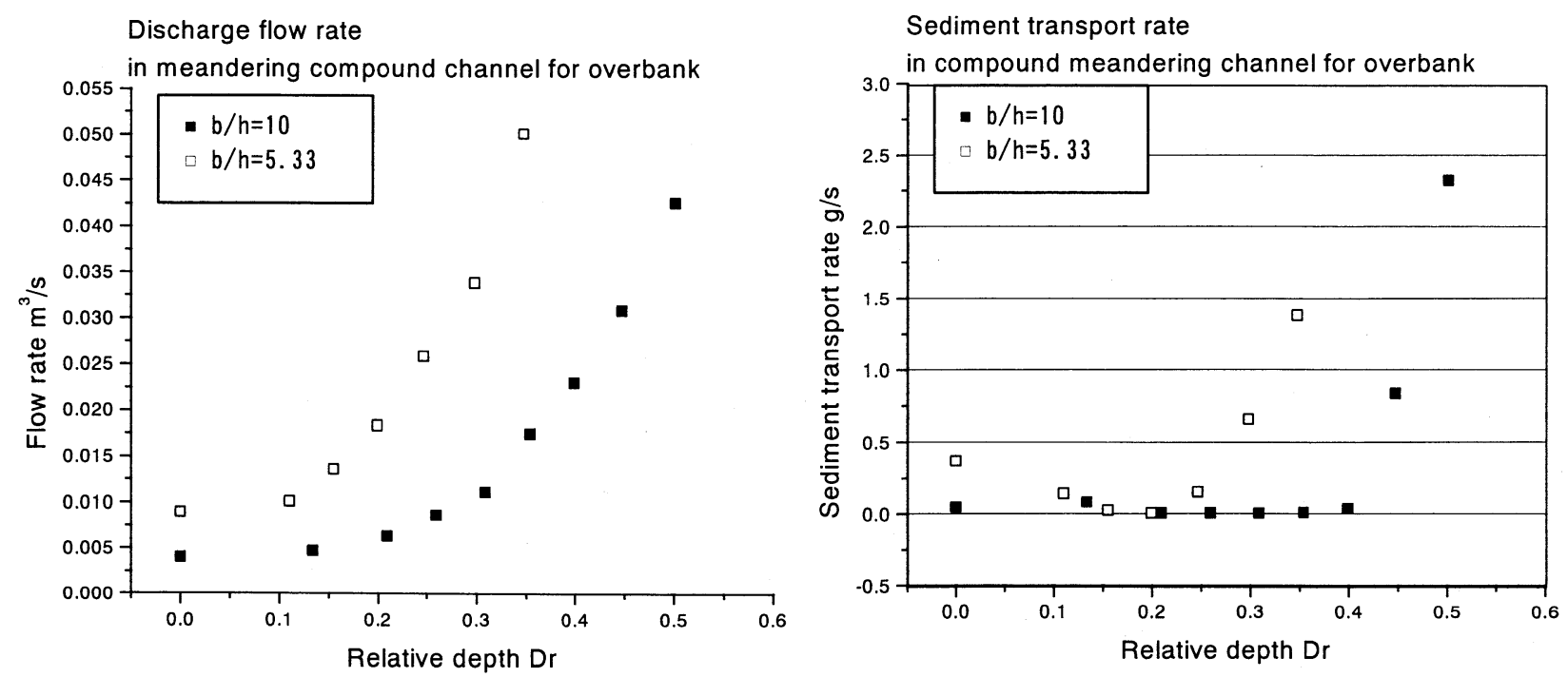

Fig. 6 Flow discharge and Sediment transport rate for two aspect ratios.

reach of the sand bar. Those two cells work each other as a counter flow to maintain a regular wavy bed form. From the bed forms with various depths, it can be said that a number of secondary flow cells are initiated by interaction between the main channel flow and flood plain flow, as mention before. These cells increase the strength as flood depth increases and then make sand bars crossing the main channel at the flood depth, $\mathrm{Dr}=0.45$. Most literature 1 , 2),3),8), only illustrate a number of floodplain induced secondary flow cells in the main channel, but the pair of the secondary flow cells has not identified in experiments. This experiment result clearly advances further understanding of secondary flow behaviour in a meandering channel for overbank flow.

\section{Sediment transport rates}

The sediment was collected for 6 hours to determine the transport rate, for example, a time series of sediment rate is shown in Fig. 5. The sediment rate varies over short time. However it settles to a mean transport rate after 6 hours. The duration of all the collected sediment was more than 6 hours. Sediment transport rates with various relative depths for two experimental cases $(\mathrm{b} / \mathrm{h}=5.33$ and 10) were plotted in Fig. 6 together with the discharge flow rates. The sediment transport rate with respect to depth variation shows interesting behaviour with the sediment rate decreasing in an early stage of the flood although the flow rate increases. For $b / h=10$, the sediment rate increases when the flood just begins and then 
decreases to almost zero transport rate. When the water depth is at $\mathrm{Dr}=0.4$ the sediment rate starts increasing rapidly. For $b / h=5.33$, the sediment rate decreases until $\mathrm{Dr}=0.2$ and starts increasing after $\mathrm{Dr}=0.2$. Therefore the sediment transport rate decreases at an early stage of flooding. This agrees with the FCF experimental result ${ }^{6}$. Shiono and Muto $^{8)}$ demonstrated that there was large production of turbulent kinetic energy at the bankfull level caused owing to interaction between the floodplain flow and the main channel flow. This interaction reduces the channel flow and bed shear stress when the floodplain flow is still smaller than the main channel flow ${ }^{9}$ ), and hence the reduction of the sediment transport rate occurs at the beginning of the flood. However when flood depth increases the floodplain flow becomes larger than the main channel flow at a certain depth, hence the main channel flow accelerates owing to the faster flood plain flow ${ }^{9}$, and then sediment transport rate increases rapidly.

\section{Conclusions}

Bed form and secondary flow structures in a compound meandering channel with having straight floodplain banks for overbank flow were investigated using photogrammetry, flow visualization and three component laser Doppler anemometer. The following phenomena were found:

1) Bed form at the water depth, $\mathrm{Dr}=0.45$, shows the existence of distinct sand bars crossing the cross-over section in the main channel. The sand bars were generated by the secondary flow cells induced owing to the floodplain flow.

2) The result of secondary flow obtained with a flow visualization technique agrees very well with that measured using three component laser Doppler anemometer. The development and decay of the secondary flow was observed along one sand bar passing through the bend apex.
3) There exists a certain relationship between the bed form and secondary flow. The floodplain induced secondary flow in the main channel generates another secondary flow cell owing to its flow crossing over the sand bar. This new secondary flow works as a counter to the floodplain induced secondary flow to maintain the sand bar.

4) Sediment transport rate at an early stage of flooding is reduced owing to strong interaction between the floodplain flow and the main channel flow.

\section{References}

1. Fukuoka, S., Ohgushi, H., Kamura, D. and Hirano, S. (1997) Hydraulic characteristics of the flood flow in a compound meandering, channel, Journal of Hydraulic, Coastal and Environmental Engineering, JSCE, II-41, pp. 83-92. (in Japanese)

2. Ishigaki, T. and Muto, Y. (1998), An experimental study on the flow in compound sinuous channels, Annual Journal of Hydraulic Engineering, JSCE, Vol.42, pp.943-948. (in Japanese)

3. Ishigaki, T., Muto, Y. and Sawai, K. (1999), Secondary flow and tractive force in compound sinuous channel, Annual Journal of Hydraulic Engineering, JSCE, Vol.43, pp.329334. (in Japanese)

4. Jansen, P.Ph., van Bendegom, L. and van den Berg, J. (1979), Principles of river engineering, the non-tidal alluvial river, Pitman, London.

5. Peterson, M.S. (1986), River engineering, Prentice-Hall, Englewood Cliffs, NJ.

6. Rameshwaran, P., Spooner, J., Shiono, K. and Chandler, J.H. (1999), “ Flow Mechanisms in two-stage meandering channel with mobile bed", Proc. $28^{\text {th }}$ Congress of IAHR Congress, Graz, Austria, p.259.

7. Shiono, K. and Knight, D.W. (1991), Turbulent open channel flows with variable depth across the channel, Journal of Fluid Mechanics, Vol. 222, pp.617-646.

8. Shiono, K. and Muto, Y. (1998), "Complex flow mechanisms in compound meandering channel for overbank flow", Journal of Fluid Mechanics, Vol. 376, pp. 221-261.

9. Shiono, K., Muto, Y., Knight, D.W. and Hyde, A.F.L. (1999), "Energy losses due to secondary flow and turbulence in meandering channel for overbank flows", Journal of Hydraulic Research, IAHR, Vol.37, No.5, pp.641-664.

(Received September 30, 1999) 